\title{
A VIRADA GEOPOLÍTICA NO BRASIL DO SÉCULO XXI OBSERVADA A PARTIR DE TELEGRAMAS DIPLOMÁTICOS VAZADOS PELO WIKILEAKS
}

\author{
Gabriel Teixeira Barros \\ Universidade do Estado do Rio de Janeiro (UERJ), Brasil \\ gabriel.t.barros@gmail.com
}

\section{A virada geopolítica no Brasil do século XXI observada a partir de telegramas diplomáticos vazados pelo Wikileaks (Resumo)}

A virada geopolítica que ocorreu no Brasil a partir de 2016, com o impeachment da Presidente Dilma Rousseff, se relacionou com a rede financeira de poder mundial. Este estudo pretende demonstrar tal fato, apresentando dados sobre a ascensão das políticas neoliberais no Brasil, nos anos 1990, e sobre a gradual ruptura política iniciada em 2003, com o governo de Luís Inácio Lula da Silva. Tal ruptura foi evidenciada nos grampos de telegramas diplomáticos estadunidenses e outros documentos disponibilizados pelo Wikileaks, por meio do posicionamento diplomático dos EUA sobre as disputas eleitorais brasileiras que ocorreram em 2010 e em 2014, a legislação de Exploração e Produção (E\&P) das reservas de petróleo do Pré-sal, a cibervigilância interestatal e a criação do "Projeto Pontes", anterior à Operação Lava Jato. Por meio de análise em documentos publicados pelo Wikileaks, é possível demonstrar como a política interna brasileira foi influenciada pelo uso de soft power, por agentes vinculados aos interesses geopolíticos estadunidenses, no período pesquisado.

Palavras-chave: Brasil, petróleo, redes de poder, Wikileaks, cibervigilância.

\section{El giro geopolítico en el Brasil del siglo XXI visto desde los cables diplomáticos filtrados por Wikileaks (Resumen)}

El giro geopolítico que ocurrió en Brasil a partir de 2016, con la destitución de la Presidenta Dilma Rousseff, se relacionó con la red de poder financiera mundial. Este estudio pretende demonstrar tal hecho, presentando datos sobre el auge de las políticas neoliberales en Brasil desde la década de 1990, y sobre la ruptura política gradual iniciada en 2003, con el gobierno de Luís Inácio Lula da Silva. Tal ruptura quedó evidente en los cables diplomáticos estadounidenses y otros documentos puestos a disposición por Wikileaks, a través del posicionamiento diplomático de EEUU sobre las disputas electorales brasileñas de 2010 y 2014, la legislación de explotación y producción de las reservas de petróleo del Pré-sal, la vigilancia cibernética interestatal y la creación del "Projeto Pontes", anterior a la Operación "Lava Jato". A través del análisis en documentos publicados por Wikileaks, es posible demostrar cómo la política interna brasileña fue influenciada, por el uso de soft power, por agentes vinculados a los intereses geopolíticos estadounidenses.

Palabras clave: Brasil, petróleo, red de poder, Wikileaks, vigilancia cibernética. 


\section{The geopolitical turn in Brazil in 2 I st century observed through diplomatic cables released by Wikileaks (Abstract)}

The geopolitical turn that occurred in Brazil in 2016, after the impeachment of former President Dilma Rousseff was related with the global power financial network. This study intend to demonstrate that fact by presenting data about the rise of neoliberal policies in Brazil in the 90's and how a gradual political rupture had occurred since 2003, under the government of former President Luís Inácio Lula da Silva. This political break became evident in the cables from USA diplomats and other files, leaked by the Wikileaks, by the political position exposed in them about the Brazilian electoral disputes of 2010 and 2014, the E\&P legislation over the pre-salt oil reserves, the international cibersurveillance and in the creation of Project Bridges, before the Operation Carwash. Through the analysis of the files published by Wikileaks, we could observe how the Brazilian internal politics was influenced, with the use of soft power tools, by agents linked to the USA geopolitical interests.

Keywords: Brazil, oil, financial networks, Wikileaks, cybersurveillance.

A presente pesquisa tem como propósito analisar como a virada geopolítica, ocorrida no Brasil a partir de 2016 - assim como em outros países da América do Sul - tem relação direta com os interesses do capital financeiro mundial. Esse se constitui em uma rede de atores influentes sociopoliticamente (o que podemos chamar de establishment mundial) que, a despeito da existência ou não de lastro de valor material desse capital, possuem em geral sede físico-espacial dentro do território dos Estados Unidos da América (EUA).

Entendendo a geopolítica atual como a preconizada por Giovanni Arrighi e Berverly Silver (2001), que tem base em Immanuel Wallerstein (1984) na sua teoria da sucessão dos ciclos hegemônicos no "sistema-mundo", e que por sua vez tem grande influência da teoria das "economias-mundo" do espaço-tempo de longa duração do historiador Fernand Braudel (2009)2, podemos associá-la à dinâmica das redes geográficas como estudada por Milton Santos (2017). Assim, é possível compreender o cenário geopolítico mundial e as intenções de cada um dos atores ativos com relação ao capital em todas as suas formas, que é a base do sistema hegemônico. O conceito de hegemonia é discutido em "Caos e governabilidade" filósofo italiano Antônio Gramsci, e entendido no âmbito da sucessão de hegemonias mundiais no sistema capitalista desde seu início até os dias atuais, como apresentado por Arrighi (1996) em O longo século XX. Sobre o capital em si, Robert Kurz (2015) e Elmar Altvater (2010) ajudam a entendê-lo de uma forma profundamente crítica, completando a vicissitude do pensamento.

Para esta pesquisa, o método primordialmente utilizado foi o da investigação bibliográfica, por meio de autores referência, como Kurz (2015) e Altvater (2010), que são críticos do sistema capitalista como esse vem se desenvolvendo desde o século XIX e teóricos de alternativas sustentáveis à sociedade global.

O texto está organizado em três partes. Na primeira, "As redes do capital financeiro mundial de lastro pós-ouro (1944)", realizo um resgate histórico acerca da mutação da relação entre o

\footnotetext{
${ }^{1}$ Arrighi e Silver, 2001, p. 39; Wallerstein, 1984, p. 44-45.

2 Braudel, 2009[1996], p. 12.

${ }^{3}$ Arrighi e Silver, 2001, p. 35.
} 
capital-moeda e o conceito de valor, que é a base do entendimento do sistema financeiro mundial desde a Conferência de Bretton-Woods até os dias atuais.

Na segunda parte "A ascensão do neoliberalismo no cenário sul-americano", abordo como essa rede se materializa no continente sul-americano por meio da ascensão das políticas neoliberais, a partir do Consenso de Washington (1989) e como ocorre o distanciamento dessas políticas no governo de Lula da Silva. Além disso, evidencio, a partir dos telegramas vazados, como essa mudança de posicionamento contrariou os interesses dos diplomatas estadunidenses no Brasil, principalmente com relação à questão de políticas públicas para o Pré-Sal e às eleições brasileiras de 2010.

Em uma terceira parte, "A eleição de Dilma Rousseff e a Primavera Árabe", analiso, por um lado, como os EUA apoiaram a oposição política brasileira nas eleições de 2010 e 2014 e idealizaram o "Projeto Pontes", que objetivava gerar cooperação jurídica contra crimes de financiamento ilícito, tendo como principal expoente o juiz Sérgio Moro; e por outro, como fomentaram a eclosão dos protestos de oposição de junho de 2013 e atuaram com sua Agência Nacional de Segurança (NSA) em ações de cibervigilância sobre a Presidente Dilma Rousseff e diretores da Petróleo Brasileiro S.A. (Petrobras). Finalmente, aponto como essa conjuntura se desdobrou no impeachment e na imediata liberalização da exploração do Pré-sal, em 2016.

Para a análise proposta, utilizo fontes primárias de dados divulgados pela organização nãogovernamental (ONG) Wikileaks, no âmbito do leak ${ }^{4}$ Cablegate $^{5}$, que consiste em uma série de telegramas diplomáticos confidenciais (classified cables), grampeados pelo Wikileaks, de embaixadas americanas e consulados gerais (Consulate General) em todo o mundo, desde 1966 até fevereiro de 2010. Este artigo contempla o conteúdo dos telegramas enviados de Consulados Gerais e da Embaixada Americana no Brasil, desde 2006 até o mais recente, versando sobre assuntos como as eleições presidenciais, os campos de petróleo do Pré-sal e o Projeto Pontes, anterior à Operação Lava Jato. Esses cables ajudam a entender a orientação geopolítica e os interesses estadunidenses no Brasil, além de serem extremamente reveladores sobre a sua participação ativa em assuntos de todo tipo dentro da política interna brasileira.

A principal categoria analítica utilizada é a das redes geográficas, onde utilizo o conceito de Milton Santos (2017) sobre a imposição de uma racionalidade única global por meio das verticalidades e horizontalidades das redes, ou seja, consonante com a dinâmica da globalização. Sobre o tema da vigilância no ciberespaço e a geopolítica dos BRICS, uso como principal referência Hindenburgo Pires (2014; 2015) e Joseph Nye (2004).

O recorte espacial tratado será o Estado-nação do Brasil, por onde as horizontalidades da rede do capital financeiro mundial se espraiam (embora não apenas dele). Já o recorte temporal abordará a segunda metade do século XX até os dias atuais, porém com especial enfoque a partir do ano de 2006.

\footnotetext{
${ }^{4}$ Um leak é a forma como o Wikileaks se refere a um grupo de publicações de documentos referentes ao mesmo tema e normalmente publicados juntos.

$5<$ https://wikileaks.org/plusd/about/>.
} 


\section{As redes do capital financeiro mundial de lastro pós-ouro (1944)}

Apesar de já passados vinte anos do início do século XXI, alguns acontecimentos do século passado ainda são peças primordiais para compreender o atual sistema-mundo globalizado em que vivemos. Para entendermos a espacialização dos fenômenos geopolíticos na América do Sul (e no Brasil), é preciso antes de tudo sintetizar como as redes do atual capitalismo financeiro começaram a se desvincular dos Estados e como atualmente ensaiam uma interdependência.

\section{O pós-Segunda Guerra e a Conferência de Bretton Woods: a pax americana dolarizada}

Após a Segunda Guerra Mundial, iniciou-se uma onda de reconstrução e financiamento mundial, promovida pelos Estados Unidos da América (EUA) como credor, por meio de diversos planos (Marshall, Colombo e outros), e que teve como consequência uma virada hegemônica mundial, segundo Arrighi (1996). Dessa forma, o capital em padrão-ouro, que antes estava disseminado pelo globo por meio da libra esterlina do vasto império inglês ${ }^{6}$, passou, a partir de então, a configurar-se de uma nova forma.

Até a Conferência de Bretton Woods (julho de 1944), todo o dinheiro mundial tinha lastro no ouro e mais de dois terços das reservas mundiais estavam armazenadas na famosa Fort Knox, base do exército dos EUA. Este fator foi decisivo para que, durante essa Conferência, se deliberasse a favor de eleger o dólar americano como a moeda mundial, já dentro da lógica da pax americana ${ }^{7}$. Ademais, essa decisão daria aos EUA, como financiador da reconstrução de vários países, uma vantagem competitiva no alcance da hegemonia mundial.

O sistema capitalista mundial viveria os seus anos dourados entre 1945 e 1977, diante de uma pulsante indústria da construção civil na Europa, da disseminação do consumismo e do crédito (por meio do american way-of-life), da corrida armamentista da Guerra Fria e das diversas guerras promovidas pelos EUA e a União das Repúblicas Socialistas Soviéticas (URSS), que mantiveram aquecidas as suas economias por meio de um vasto complexo industrial-militar. Toda essa conjuntura possibilitou a vigência do chamado welfare state nos países centrais, principalmente nos estados europeus, como a Inglaterra, a França e os países escandinavos.

\section{O fim do lastro no ouro com Richard Nixon}

Era nítido que esse ciclo estava fadado a acabar, pois o dinheiro mundial girava cada vez mais desespacializado, financiando o consumismo mundial e aumentando a dívida pública de todos os países com relação aos EUA. As reservas auríferas de Fort Knox esvaíram-se rapidamente até meados dos anos 1970. A partir disso, o Banco Central Americano (o Federal Reserve, ou FED), por meio do Banco Mundial e do Fundo Monetário Internacional (FMI), viu-se na necessidade de agir. Essas instituições foram criadas no pós-guerra e, apesar de constituírem-se em organismos mundiais, suas lideranças sempre sofreram forte influência dos EUA.

Foi no governo de Richard Nixon, em 1973, que decretou-se o fim da convertibilidade do dólar americano em ouro ${ }^{8}$. Esse fato é primordial para entender o atual sistema capitalista mundial, que, a partir daí, teria ganhado mais nitidamente as características de um capitalismo financeiro. Porém, voltemos aos anos 1970 para entender o cenário de crise que levou a esse fato.

\footnotetext{
${ }^{6}$ Kurz, 2015, p. 24.

${ }^{7}$ Kurz, 2015, p. 25.

${ }^{8}$ Kurz, 2015, p. 26.
} 


\section{O fim do welfare-state e a ascensão das políticas neoliberais}

Na década de 1980, após a Crise do Petróleo, o capital monetário já havia perdido a sua substancialização e as reservas internas dos países não podiam mais suplantar sozinhas o aparato do complexo militar-industrial. Tem-se o fim das políticas keynesianas e a adoção de medidas neoliberais em países como Grã-Bretanha, sob o governo de Margaret Thatcher, e EUA, com Ronald Reagan ${ }^{9}$. Com isso, inicia-se a mundialização do financiamento por meio da venda de títulos do tesouro americano (T-bonds), de ativos empresariais e de ativos imobiliários. Nas palavras de Kurz:

Era precisamente o poder militar dos EUA como polícia mundial que parecia oferecer um porto seguro aos mercados financeiros globais. Esta impressão iria ainda reforçar-se consideravelmente após a suposta vitória sobre o sistema contrário do Leste. O dólar conservou a sua função de dinheiro mundial ao metamorfosear-se de dólar-ouro em dólar-armamento. E o caráter estratégico das guerras de ordenamento mundial, nos anos 1990 e após a virada do século, no Oriente Médio, nos Bálcãs e no Afeganistão, consistia em primeira linha em perpetuar o mito do porto seguro e, com ele, o dólar como moeda mundial através da demonstração de capacidade de intervenção militar global ${ }^{10}$.

O conceito-elo que faltava para entender a questão do capitalismo mundial é apresentado aqui por Altvater (2010) que, visto em conjunto com o que defende Kurz (2015), permite demonstrar que o capitalismo financeiro mundial está estritamente vinculado à disponibilidade e ao preço do petróleo, já que este alimenta e é a base do complexo militar-industrial, o porto seguro americano. Em suma, todo o capitalismo está vinculado à produção de mais-valia (Marx) e ao emprego do trabalho para geração de valor. Após a Revolução Industrial, os detentores dos meios de produção passaram a aumentar sua margem de lucro e eficiência das linhas de produção, ao empregar o uso das máquinas a vapor. De início, tem-se o uso da madeira como fonte de energia primária - até que a energia gasta na extração dessa suplantasse o seu benefício de uso chegando-se finalmente ao uso de energias fósseis como o carvão e, finalmente, o petróleo ${ }^{11}$. Para Altvater, essa é a trindade essencial formada por "capitalismo, fontes fósseis de energia e racionalidade industrial de meios e fins", que "produz uma aceleração de todos os processos econômicos e sociais única na história da humanidade"12. Essa dependência do petróleo para a produção de mais-valia, aliada à chamada forma de apropriação da "valorização primária"13, gera uma mudança no tabuleiro mundial geopolítico, visto que agora "não está em jogo o deslocamento de fronteira entre Estados-nação [..] como no "velho imperialismo", mas "sobretudo a fronteira da disponibilidade de petróleo, a seiva das economias modernas. $\mathrm{O}$ objetivo do imperialismo petroleiro é o deslocamento da fronteira de disponibilidade"14. Portanto, estão dadas as bases para o entendimento da questão geopolítica brasileira e sulamericana, a qual focarei na seção seguinte.

\section{A ascensão do neoliberalismo no cenário sul-americano}

\footnotetext{
${ }^{9}$ Batista, 1994, p. 6.

${ }^{10}$ Kurz, 2015, p. 29.

11 Altvater, 2010, p. 120.

12 Altvater, 2010, p. 123.

13 Altvater, 2010, p. 88. O autor aborda o conceito a partir da página 88 e cita David Harvey (2003, p. 17), que correlaciona os métodos da valorização primária em referência com a descrição da "acumulação primitiva do capital", feita por Marx, no capítulo 24 do primeiro volume de "O capital".

14 Altvater, 2010, p. 222.
} 
O Consenso de Washington, em 1989, marcou o estabelecimento de um padrão político que foi adotado em toda a América Latina, com o aval das grandes autoridades mundiais como o Banco Mundial e o FMI, e que seria condição sine qua non para a concessão de financiamento ${ }^{15}$. $\mathrm{O}$ encontro, inicialmente marcado por um tom majoritariamente acadêmico, acabou por tomar a importância de um tratado internacional, pois definiu a postura de diversas entidades intelectuais e, principalmente, da elite industrial latino-americana, representada no Brasil por organizações como a FIESP. Como afirma Paulo Nogueira Batista:

Exemplo desse processo de cooptação intelectual é o documento publicado em agosto de 1990 pela Fiesp, sob o título "Livre para crescer - Proposta para um Brasil moderno", hoje na sua $5^{\text {a }}$ edição, no qual a entidade sugere a adoção de agenda de reformas virtualmente idêntica à consolidada em Washington ${ }^{16}$.

Essas políticas exprimiam uma necessidade econômica dos países centrais de aliviarem a bolha do financiamento, disponibilizando crédito para novos mercados consumidores e expandindo a expectativa de recebimento de juros. Porém, a verdade é que não havia por parte desses países a vontade de receber o pagamento da dívida, mas sim de minar a independência dos Estados-nação mais suscetíveis (os ditos "em desenvolvimento"), em troca da total liberalização de seus recursos, seja por meio da possibilidade da exploração direta (venda) ou indireta (concessões). As políticas de Washington não possuíam qualquer preocupação com o desenvolvimento social dos países credores, ao contrário fomentavam o retorno a uma utopia liberal do laissez-faire do fim do século XIX, que há muito já havia se mostrado ultrapassada. Esses ideais rompiam completamente com os preconizados pela Comissão Econômica para América Latina e Caribe (CEPAL), que nas décadas anteriores foram importantes balizadores políticos no continente americano $^{17}$. Para ilustrar, cito novamente Paulo Batista:

O Consenso de Washington não tratou tampouco de questões sociais como educação, saúde, distribuição da renda, eliminação da pobreza. Não porque as veja como questões a serem objeto de ação numa segunda etapa. As reformas sociais, tal qual as políticas, seriam vistas como decorrência natural da liberalização econômica. Isto é, deverão emergir exclusivamente do livre jogo das forças da oferta e da procura num mercado inteiramente auto regulável, sem qualquer rigidez tanto no que se refere a bens quanto ao trabalho. Um mercado, enfim, cuja plena instituição constituiria o objetivo único das reformas. [...] Em resumo, uma proposta saudosista, tentada sem sucesso e com consequências negativas na Europa da década de 20, de retorno ao laissez-faire do final do século XIX e princípio do século atual, da ordem liberal comandada pelo "padrão ouro", que a I Guerra Mundial destruiria ${ }^{18}$.

A década de 1990 na América Latina foi um período de ascensão de governos liberais. No Brasil, até 2002, Fernando Collor de Melo, Itamar Franco e Fernando Henrique Cardoso seguiram a cartilha do Consenso de 1990, promovendo a dolarização do real (vinculação da moeda nacional ao dólar americano), a desestatização de setores-chave da economia nacional (vale citar a privatização da mineradora e siderúrgica Vale do Rio Doce) e a concessão de subsídios de diversos tipos às multinacionais estrangeiras em diversas regiões do país, como a criação dentro do âmbito do Plano Plurianual (1996-1999) dos 12 "Eixos Nacionais de Integração e Desenvolvimento" ${ }^{19}$. Friso ainda que a Constituição de 1988, dando maior autonomia aos

\footnotetext{
${ }^{15}$ Batista, 1994, p. 7.

${ }^{16}$ Batista, 1994, p. 6.

${ }^{17}$ Martinez e Oliveira, 2016, p. 74

${ }^{18}$ Batista, 1994, p. 11.

${ }^{19}$ Bacellar, 1999, p. 84.
} 
Municípios e Estados, também contribuiu para fomentar a "guerra dos lugares" 20 entre os entes federativos, pois possibilitou a disputa de Estados e Municípios em busca do oferecimento de melhores condições à instalação do capital multinacional por meio de subsídios tributários.

Entre os governos neoliberais participantes desse período histórico estão Carlos Andrés Perez (1989-1993) e Rafael Caldera (1994-1998) na Venezuela ${ }^{21}$; Carlos Saul Ménem na Argentina (1989-1999); Patrício Alwyin (1990-1994), Eduardo Frei-Ruiz Tagle (1994-2000) no Chile ${ }^{22}$ e Alberto Fujimori (1990-2000) no Peru.

\section{Novas políticas de integração sul-americanas e a reação estadunidense}

Os governos de Luís Inácio Lula da Silva (2003-2010) e de Dilma Rousseff (2010-2016), configuraram uma virada no rumo das políticas públicas brasileiras, principalmente no que concerne a programas sociais de distribuição de renda (Bolsa-Família, Fome Zero e outros) e à política externa brasileira, que, de ocupar uma cadeira temporária no Conselho de Segurança da ONU, passou a pleitear uma vaga definitiva. As políticas distributivas do Partido dos Trabalhadores (PT), unidas à diminuição da Taxa Básica de Juros (SELIC) e a outros incentivos pontuais, como a redução do Imposto sobre Produtos Industrializados (IPI) em $2012^{23}$ (que aqueceu a indústria automobilística), estimularam fortemente o consumo que, juntamente com o aumento do preço dos commodities, propiciaram um crescimento jamais visto no Brasil. A guinada política brasileira foi acompanhada por vários países da América Latina, como a Venezuela de Hugo Chávez, a Argentina de Nestor e Christina Kirchner, o Equador de Rafael Corrêa, o Chile de Michelle Bachelet, o Paraguai de Fernando Lugo, a Bolívia de Evo Morales e o Uruguai de José Mujica.

Essa mudança ideológica em relação ao papel do Estado na economia trouxe um iminente conflito regional entre a América do Sul e os EUA, que sempre mantiveram um forte controle sobre os rumos da política no continente. O fortalecimento desses Estados-nação estava permitindo a esses países um maior controle sobre seus recursos - naturais e econômicos - o que desagradou aos interesses de Washington e Wall Street. Além disso, neste período houve uma clara aproximação econômica e política entre estes países e China, país cujos indicadores apontavam, um papel relevante na economia mundial da segunda década do século $\mathrm{XXI}^{24}$. Kurz (2015) analisa como a instalação de redes mundiais de produção industrial no sudeste asiático contribuiu para a formação do "Circuito de Débito do Pacífico" (Círculo de Déficit Global), que a través da absorção dos fluxos excedentários globais de mercadorias têm movido a economia mundial e ao mesmo tempo aumentado o déficit estadunidense com relação aos países asiáticos

\footnotetext{
${ }^{20}$ Santos, 2017; Rolnik, 2015. Apesar de Rolnik usar o termo "guerra dos lugares" para falar majoritariamente sobre políticas habitacionais e reformas fundiárias em menor escala, acredito que a comparação seja coerente por se tratar de iguais bases e processos do capitalismo financeiro.

${ }^{21}$ Wilhelm, 2011, p. 260.

${ }^{22}$ Martinez e Oliveira, 2016, p. 76.

${ }^{23}<$ https://economia.uol.com.br/noticias/redacao/2012/05/21/governo-zera-ipi-de-carro-10-e-da-mais-prazo-parafinanciar.htm>.

${ }^{24}<$ https://data. worldbank.org/indicator/NV.IND.TOTL.CD?end=2018\&locations=CN-US-IN-GB\&start=2000>. <https://data.worldbank.org/indicator/NY.GDP.MKTP.KD.ZG?end=2018\&locations=CN-US-INGB\&most_recent_year_desc $=$ false\&start $=2000 \&$ view $=$ chart $>$. $<$ https://data.worldbank.org/indicator/NE.CON.TOTL.KD.ZG?end=2018\&locations=CN-US-INGB\&start $=2000>$.
} 
(China e Índia) ${ }^{25}$. Segundo o autor, "deste modo, os EUA tornaram-se o buraco negro da economia mundial" 26 .

A esta conjuntura, se une o fato do Brasil anunciar em 2008, a descoberta de enormes possíveis reservas de petróleo a serem exploradas na chamada zona do Pré-sal, o que elevou o país, perante os olhos internacionais, a um nível próximo ao da Venezuela, membro da OPEP e principal exportador de petróleo e gás natural do continente.

\section{A ascensão dos BRICS e o incômodo estadunidense sobre as políticas para o Pré-sal no Brasil}

A partir dos anos 2000, os BRICS ganham grande importância nessa nova configuração geopolítica mundial, tendo a China como financiadora, a Rússia como braço militar e energético, a Índia, o Brasil e a África do Sul como grandes polos de recursos naturais e mercados consumidores. Com o avanço da cooperação entre esses países, surgiram propostas para a criação do Novo Banco de Desenvolvimento (NBD) e do Fundo de Reservas (FR). Nas palavras de Hindenburgo Pires:

A criação do NBD do BRICS teve o propósito de superar o atraso existente na gestão administrativa das duas principais instituições financeiras - o Fundo Monetário Internacional (FMI) e o Banco Mundial, constituídas em 1944, na conferência mundial de Bretton Woods, realizada no Estado americano de New Hampshire, para estabelecer as novas bases e a segurança do sistema econômico e monetário internacional, do pós-guerra. Ainda hoje em pleno século XXI, a presidência do Banco Mundial é reservada apenas a cidadãos estadunidenses e a direção do FMI, a cidadãos europeus. No FMI, a União Europeia possui um terço dos votos e quase vinte por cento da economia mundial, ou seja, não houve um ajuste nessas entidades que ajudasse a promover uma mudança no quadro geopolítico, principalmente na definição da importância que economias nacionais deveriam merecer ${ }^{27}$.

As ações coordenadas dos BRICS demonstravam grande potencial para desbancar a hegemonia mundial estadunidense, que poderia ver-se reduzida, acarretando a necessidade de maior lastreamento do capital no dólar americano e de aquecer seu complexo militar-industrial, e isso certamente não ocorreria sem uma reação unilateral de Washington.

Desde o anúncio da descoberta do Pré-sal em 2008, os diplomatas americanos que desempenhavam suas funções no Brasil mantiveram-se bem atentos e informados sobre as questões políticas em andamento, como mostram os documentos confidenciais (confidential) disponibilizados pelo Wikileaks. Um telegrama diplomático confidencial denominado "Can the oil industry beat back the pre-salt law?"28, datado de 21/12/2009 e assinado por Dennis W. Hearne (Cônsul Geral dos EUA no Rio de Janeiro) em conjunto com a embaixada americana em Brasília, alerta a Secretária de Estado Americano (à época Hillary Clinton) sobre a preocupação das "Empresas Petrolíferas Independentes e Internacionais" (International and Independent Oil Companies - IOC) com as políticas estatais brasileiras para a exploração do Pré-sal.

Tais políticas determinavam um protagonismo da Petrobrás, o que possivelmente beneficiaria às empresas estatais chinesa e russa. O telegrama cita o lobby feito pelas IOC na Câmara dos

\footnotetext{
25 <http://www.obeco-online.org/rkurz283.htm>

${ }^{26}$ Kurz, 2015, p. 31.

${ }^{27}$ Pires, 2015, p. 289.

28 "Pode a indústria do petróleo derrubar a Lei do Pré-sal?"
} 
Deputados, e posteriormente no Senado, para tentar mudar a lei. Por fim, Patrícia Pradal, encarregada das relações governamentais da Chevron e diretora do Instituto Brasileiro de Petróleo, Gás Natural e Biocombustíveis (IBP) aponta a omissão, durante esse debate, do principal partido oposicionista - o PSDB -, sob a liderança do então governador do estado de São Paulo, José Serra. A seguir, transcrevo parte do telegrama enviado, que expõe a opinião de diretores de empresas petrolíferas americanas (Chevron e Exxon Mobil) sobre o citado protagonismo da Petrobras nos Acordos de Partilha da Produção (Production Sharing Agreement - PSA):

A indústria continua a afirmar que o aspecto mais prejudicial sobre o quadro de viabilidade comercial das operações futuras no Pré-sal é a designação da Petrobras como operador-chefe, que é parte da proposta governamental no "Acordo de Partilha". Reafirmando a posição que apresentou ao Encarregado de negócios (Charge D'Affaires) em 1 de setembro (telegramareferência "B"), Lacerda, da Exxon, disse que ter a Petrobras operando todos os blocos do PréSal efetivamente relegaria as empresas petrolíferas a meros agentes financiadores. Robert Abib, do "Anadarko", disse em 19 de novembro que o papel da Petrobras como operador-chefe poderia afastar as empresas petrolíferas independentes e de menor porte, caso os focos da paraestatal fossem nos maiores campos do Pré-sal, em vez dos menores, onde as empresas independentes normalmente são especializadas e focam suas operações. Lacerda, da Exxon, reclamou que o "Acordo de Partilha" falhou em definir de forma suficiente os termos fiscais atribuídos aos contratos, e disse que, sobre o regime proposto, esses termos apenas se tornariam claros imediatamente antes de uma rodada de leilões, tornando quase impossível para uma empresa se preparar adequadamente. Ambos, Pradal do IBP, e Lacerda disseram que o debate em questão sobre a distribuição dos royalties da produção de petróleo aos Estados produtores e nãoprodutores, Municípios e o Governo Federal, que também é parte do "Acordo de Partilha", estavam impedindo qualquer discussão real sobre a transparência e capacidade do negócio em atrair investimentos ${ }^{29}$.

Porém, seus mais significativos depoimentos tratam do aumento da participação das National Oil Companies (NOC) no mercado brasileiro e como isso afeta a competitividade das empresas estadunidenses em relação às futuras partilhas dos campos de petróleo.

Caso a designação da Petrobras como operador-chefe se mantenha, Pradal, do IBP, disse que seria impossível competir em rodadas de leilão contra as Empresas Petrolíferas Estatais (NOC), como a SINOPEC da China e a GAZPROM da Rússia. De acordo com Pradal, o leilão sairia para quem oferecesse ao governo o maior lucro. "Os Chineses podem cobrir as ofertas de todos", ela explicou. "Eles podem inclusive ficar no zero e isso continuará sendo atrativo para eles. Eles só querem o petróleo". Pradal disse que a Chevron não deveria nem competir sobre essas circunstâncias. (Nota: Prevendo um maior investimento das NOC no Brasil, a empresa petrolífera 90\% estatal da Colombia, Ecopetrol, abriu um escritório no Rio de Janeiro em 18 de novembro. Após, o CFO da Petrobras, Barbassa, disse em 23 de novembro que a paraestatal deverá mandar altos-executivos para a China logo no início de 2010, em um esforço para atrair empresas fornecedoras de equipamentos de suporte à indústria de petróleo para o Brasil ${ }^{30}$.

Esses telegramas denotam uma grande preocupação dos diplomatas americanos em atividade no Brasil com a situação das empresas multinacionais petrolíferas sediadas nos EUA (Chevron e Exxon Mobile) e a sua capacidade de participação na exploração do Pré-sal brasileiro. Ainda, as empresas estatais chinesas e russas (SINOPEC e GAZPROM) são vistas como uma ameaça por

\footnotetext{
${ }^{29}<$ https://search.wikileaks.org/plusd/cables/09RIODEJANEIRO369_a.html> Tradução literal do autor.

$30<$ https://search.wikileaks.org/plusd/cables/09RIODEJANEIRO369_a.html> Tradução literal do autor.
} 
Patrícia Pradal. Todo o telegrama confidencial demonstra uma íntima relação do governo americano com os interesses de Exploração e Produção $(E \& P)^{31}$ das IOC no Pré-sal brasileiro, e, por consequência, nas eleições presidenciais de 2010, pois Lula é visto como um empecilho aos interesses dessas empresas, como fica claro no trecho em que Carla Lacerda - naquele momento Diretora de Relações Internacionais da Exxon Mobil e depois presidente da empresa no Brasil - atribui os termos insatisfatórios do PSA ao Diretor de E\&P da Petrobras Guilherme Estrella:

Por outro lado, Lacerda, da Exxon, disse que o Diretor de Exploração e Produção da Petrobras, Guilherme Estrella, foi o maior responsável pelos termos do "Acordo de Partilha" que prejudicaram as empresas petrolíferas internacionais. (Nota: Estrella comparou publicamente a Petrobras a um programa de exploração espacial, em termos de ambições nacionais, e é considerado próximo ao Presidente Lula. Fim da Nota) ${ }^{32}$.

Certamente, os comentários acima expostos não significam oficialmente a opinião do governo americano sobre o assunto, apesar de serem claramente relevantes para ele. Ao fim do documento é exposto o comentário (conclusão) do Cônsul Geral dos EUA no Rio de Janeiro, Dennis Hearne (2009-2012), sobre a situação:

Além disso, mesmo que as IOC consigam ao menos forçar um atraso em uma votação do Senado até uma possível - mas incerta - vitória de um presidente da oposição, há um consenso de que a espera para ofertar em oportunidades comerciais mais atrativas no Pré-sal será longa. Essa perspectiva, assim como a atratividade limitada de blocos próximos ao litoral (onshore) e a incerteza das fronteiras dos campos de petróleo offshore comuns, prejudicam a habilidade das IOC de efetivamente traçar suas operações locais, e ameaçam seu interesse geral no Brasil ${ }^{33}$.

Em outro telegrama confidencial enviado à Secretaria de Estado Americano, desta vez da Embaixada em Brasília, mas contando com colaboração dos Consulados Gerais em São Paulo e no Rio de Janeiro e intitulado "Brazil's presidential elections: Dilma Rousseff comes up fast behind Jose Serra" ${ }^{34}$, datado de 13/02/2010, assinado por Thomas Shannon Jr. - o próprio embaixador (2010-2013) - e classificado como Confidential por Lise Kubiske, Chefe da Missão Diplomática (2008-2011) ${ }^{35}$, é relatado o seguinte:

9. (C) Após meses aquecendo seus motores, os dois mais prováveis competidores à Presidência do Brasil estão postos na linha de largada, ambos bem posicionados nas intenções de voto, assim como a maioria dos analistas previra para eles a este ponto. $\mathrm{O}$ esperado anúncio oficial de Rousseff, programado para logo após o Carnaval (aproximadamente 20 de fevereiro), levará a outra rodada de especulações sobre os planos de Serra até o momento em que ele finalmente os anunciará (ou não) em março, marcando o início de fato de sua campanha. A corrida, desse ponto em diante, se tornará muito difícil de prever, por conta de ambos mensuráveis "fatores $\mathrm{x}$ " como as candidaturas de Ciro Gomes e Marina Silva, e por conta de variáveis quase impossíveis de prever - como o impacto da ainda-indefinida estratégia de campanha de Serra ou se as

\footnotetext{
${ }^{31}$ Exploração e Produção $(E \& P)$ refere-se a um "conjunto de operações destinadas à exploração e à produção de petróleo e/ou de gás natural". <http://dicionariodopetroleo.com.br/dictionary/ep/>.

$32<$ https://search.wikileaks.org/plusd/cables/09RIODEJANEIRO369_a.html> Tradução literal do autor.

33 <https://search.wikileaks.org/plusd/cables/09RIODEJANEIRO369_a.html> Tradução literal do autor.

34 "Eleições presidenciais brasileiras: Dilma Rousseff vem rápido atrás de José Serra."

35 Thomas Shannon Jr. foi indicado por Barack Obama para ser o novo embaixador estadunidense no Brasil, em 24/12/2009, mas só chegou à embaixada em Brasília na data de 04/02/2010. A Chefe da Missão Diplomática, Lise Kubiske, é a segunda na hierarquia e os Consulados Gerais são postos regionais, onde o Principal Officer é o maior responsável, denominado em português de Cônsul Geral.
} 
dificuldades do PT em manter sua coalizão unida nas eleições Estaduais e para o Congresso terão algum efeito real na escolha dos eleitores na votação presidencial de Outubro. A este ponto, considerando que Serra vá concorrer, a corrida presidencial no Brasil é a definição de um caraou-coroa ${ }^{36}$.

Nesse telegrama, em trechos anteriores não transcritos aqui, é possível notar a colaboração de influentes personalidades brasileiras (sources, como assim descritos no telegrama) com o Consulado Geral em São Paulo, que, em diferentes momentos, deram suas opiniões sobre a cena política brasileira. Foram citados nomes como Humberto Saccomandi, editor de notícias internacionais do jornal "Valor Econômico", o analista político Rafael Cortez da "Tendência Consultoria", além de William Waack, ex-jornalista da "Rede Globo de Televisão", Hélio Gurovitz, editor de notícias da "Revista Época", e até políticos, como os senadores Sérgio Zambiasi (PTB-RS), Osmar Dias (PDT-PR) e Álvaro Dias (PSDB-PR).

\section{A eleição de Dilma Rousseff e a Primavera Árabe}

Claramente, a eleição de Dilma Rousseff em 2010 foi uma frustração para os interesses de Washington e dos mercados financeiro e petrolífero no Brasil. E, apesar de seu governo ter sido marcado por uma política econômica mais austera em certos setores da economia, manteve importantes projetos sociais e de soberania nacional, como a construção do primeiro submarino nuclear brasileiro (que tem relação direta com a defesa dos campos de Pré-sal). Os contatos próximos com a China e a continuidade do desenvolvimento dos planos dos BRICS, principalmente o Novo Banco de Desenvolvimento (NBD), foram também características de seu governo. Porém, o governo Rousseff sofreu com a queda do preço dos commodities, a alta dos juros e o endividamento internacional devido à Crise de 2008 (que o país conseguiu adiar por certo tempo em razão da grande reserva de dólares americanos acumulada durante o governo de Luís Inácio Lula da Silva). Em termos de infraestrutura, Rousseff priorizou o investimento na parte energética (cito a construção da Usina de Belo Monte), porém a falta de investimentos em infraestrutura de produção, transformação e logística industrial foram um ponto negativo de seu governo.

Após a fase crítica das exaustivas guerras do Afeganistão e Iraque, os EUA passaram a adotar uma renovada arma geopolítica para resolver, de maneira menos violenta, conflitos em Estadosnação menos fortalecidos e desassistidos: o soft power. A globalização, a disseminação das redes comunicacionais e de informação e a mundialização das redes sociais (principalmente o Facebook) possibilitaram mais do que nunca o estabelecimento de uma hegemonia cultural e o uso voluntário e involuntário do soft power, que é a arma mais estimada da guerra do novo milênio e estimula a ampliação do controle sobre o ciberespaço: a cibervigilância.

Soft power não é simplesmente o mesmo que influenciar. Apesar de tudo, ainda pode restar influência no hard power das ameaças ou dos pagamentos, e soft power é mais do que apenas persuasão ou a habilidade de convencer pessoas em um debate, embora seja uma importante parte disso. É também a habilidade de atrair, e atração frequentemente leva a aquiescência. Em termos de recursos, os recursos do soft power são todas as vantagens que produzem tal atração. [...] Hard

\footnotetext{
36 <https://wikileaks.org/plusd/cables/10BRASILIA49_a.html> Tradução literal do autor.
} 
e soft power estão relacionados porque são ambos aspectos da habilidade de alcançar um propósito específico por meio da afetação do comportamento de outros ${ }^{37}$.

Isso se reflete não só de forma passiva ou orgânica, como sugere o conceito de hegemonia cultural gramsciana, mas também de forma ativa e consciente. Essa ação voluntária ocorre na promoção e financiamento de ONGs em territórios estrangeiros e na disseminação ideológica por meio de cooperação e financiamento dos chamados think tanks ${ }^{38}$ globais e regionais. A ação dos think tanks pelo mundo se dá por meio da promoção de eventos de capacitação e disseminação da ideologia neoliberal, fomentando e apoiando movimentos sociais, como a Students for Liberty, que tem sua versão brasileira no Movimento Brasil Livre (MBL). São financiados por fundações de bilionários, como a John Templeton Foundation, ligada à Família $\mathrm{Koch}^{39}$, e a própria empresa petrolífera Exxon Mobile ${ }^{40}$. Recebem apoio da grande mídia global ${ }^{41}$ e a chancela de organismos internacionais supostamente neutros, como a Organização das Nações Unidas (ONU) - a chanceler da pax americana - e a Organização do Tratado do Atlântico Norte (OTAN), que participaram ativamente das negociações políticas durante a Primavera Árabe, principalmente na Líbia ${ }^{42}$.

A Primavera Árabe, como ficou conhecida pela mídia internacional, não foi um movimento totalmente espontâneo, gerado por uma súbita tomada de consciência de uma classe média aguerrida por liberdade que se organizou por meio das redes sociais, como foi amplamente disseminado pelos principais veículos midiáticos. As consequências da revolta em cada país foram também resultantes de uma intervenção geopolítica voluntária de governos ocidentais contra regimes ditatoriais que não mais atendiam aos seus interesses econômicos. Exemplo disso foi que, sem a intervenção dos países ocidentais, os protestos ocorridos na Arábia Saudita, um regime autoritário wahabista onde parte significativa da população tinha - e têm - acesso às redes sociais $^{43}$, não resultaram em mudanças políticas radicais.

Altvater (2010) expõe com clareza o interesse estadunidense nessas regiões ao dizer:

Não importa o que a retórica do livre comércio possa sugerir: com uma oferta restrita por força de limites naturais e uma demanda crescente por força de fatores econômicos, é impossível formar preços equilibrados de mercado. Por isso, as regiões de extração conhecidas, sobretudo aquelas que tem reservas elevadas, não apenas possuem uma eminente relevância geoeconômica, mas, antes de mais anda, uma eminente relevância geoestratégica. Essas regiões são o Oriente Médio e o Oriente Próximo, isto é, a península arábica, a região do Golfo e o Cáucaso Ocidental, a Ásia Central a leste do mar Cáspio, além de regiões africanas do Sudão Meridional, no leste até a Nigéria, e no oeste, até a Mauritânia. A estratégia de segurança do acesso ao petróleo por parte dos poderosos países consumidores visa a essas regiões. Ao lado delas, também entram na mira

\footnotetext{
${ }^{37}$ Nye, 2004, p. 5-6. Tradução do autor.

${ }^{38}$ São organizações produtoras de informação, que buscam influenciar o debate político, divulgando suas opiniões e os interesses de seus financiadores, por meio da participação em diferentes tipos de mídia.

39 <https://www.cartacapital.com.br/politica/quem-sao-os-irmaos-koch-2894.html>.

${ }^{40}$ Estas, por sua vez, fazem parte de uma rede internacional de think tanks cujo centro é a Atlas Economic Research Foundation Network. A Exxon Mobile doou US\$ 967.500 para a Atlas Network em um único ano, segundo dados da Conservative Transparency. <https://apublica.org/2015/06/a-nova-roupa-da-direita/>.

${ }^{41}$ Altvater, 2010, p. 257.

${ }^{42}<$ https://internacional.estadao.com.br/noticias/geral,onu-autoriza-intervencao-na-libia,693415>. <https://www.cartamaior.com.br/?/Coluna/A-Libia-a-Otan-e-o-Grande-Medio-Oriente/20882/>.

${ }^{43}$ A Arábia Saudita possuía mais usuários do Twitter (0,47\% em 2011) e do Facebook (8,29\% em 2010) por habitante de 13 anos ou mais do que Egito, Tunísia, Líbia e Síria individualmente. $<$ https://www.arabsocialmediareport.com/>.
} 
dos EUA o México, a Venezuela, a Colômbia, a Rússia, o Azerbaijão, o Cazaquistão, a Nigéria e Angola ${ }^{44}$.

Não por acaso os países que participaram da chamada Primavera Árabe localizam-se nas regiões acima citadas por Altvater: Tunísia (General Ben Ali, deposto em 2010), Egito (Presidente Hosni Mubarak, deposto em 2011) e Líbia (chefe-de-estado Muammar Kadhafi, deposto em 2011). A guerra na Síria de Bashar al-Assad, o mais novo alvo da "guerra contra o terrorismo e pela democracia" estadunidense, tem como algumas de suas principais razões não só o posicionamento estratégico de gasodutos que conectam o Golfo e a Ásia Central ao Mar Mediterrâneo, mas também um nítido reposicionamento geopolítico com relação à Rússia, conflito que se observa também na Ucrânia (questão da Crimeia em 2014) e na Turquia (outro país que sofreu uma tentativa de golpe de Estado contra o presidente eleito Recep Tayyip Erdogan, em 2016).

À lista descrita anteriormente, formulada por Altvater (2010), incluo o Brasil. Não só pela disponibilidade de petróleo, mas pela facilidade de apropriação deste recurso sem o uso da força. Historicamente, o país sempre esteve subordinado aos interesses políticos estadunidenses, com exceção do curto período em que o PT esteve no poder, o que se evidencia fortemente no posicionamento brasileiro quanto à questão do programa nuclear iraniano em $2010^{45} \mathrm{e}$ às sanções impostas aos EUA pela Organização Mundial do Comércio (OMC) por conta de suas políticas protecionistas abusivas atuantes no preço do algodão nacional (WT/DS267) ${ }^{46}$.

É certo que os principais elementos do Estado de bem-estar social estavam ausentes nos países onde ocorreram estas revoltas, e isso, certamente, foi primordial para a eclosão desses movimentos. Porém, para que tais movimentos se disseminassem ganhando relevância, era necessário um nível de organização, financiamento e direcionamento. No caso da Primavera Árabe, houve muita pressão internacional para a derrubada dos governos da Tunísia, Líbia e Egito, inclusive com bloqueios financeiros aos governos nacionais, financiamento de milícias rebeldes e reuniões da OTAN deliberando sobre o futuro desses países. Sendo assim, não me parece que tais eventos possam ser atribuídos unicamente a uma narrativa, de mais fácil apreensão, de que foi a globalização que possibilitou, por meio da Internet, o conhecimento da democracia pelos povos árabes, como se um novo Iluminismo proveniente do Ocidente estivesse a pairar sobre o Oriente, que, diante da nova perspectiva, revoltou-se.

A relação entre a Primavera Árabe e o impeachment da Presidente Dilma Rousseff não é uma relação direta de causa e efeito, mas ambos são, possivelmente, consequências de um mesmo processo macropolítico engendrado por uma maior disseminação de determinados ideais políticos, promovida em parte por think tanks globais e seus financiadores. Mais pesquisas são necessárias para determinar se ambos os movimentos são originários de um mesmo ator políticofinanceiro ou se têm origens em atores diferentes, porém algumas similaridades entre os movimentos nos levam a essa questão, como sua pretensa espontaneidade, o apartidarismo e sua organização predominantemente feita pelas mídias sociais contando com grande participação de jovens de classe média. Ainda, chama atenção, o fato destes movimentos terem como consequência direta a queda de governantes que tinham em comum não compactuarem com os interesses estadunidenses para a política internacional do comércio de petróleo, sendo esses

\footnotetext{
${ }^{44}$ Altvater, 2010, p. 256.

45 <https://www.bbc.com/portuguese/noticias/2009/11/091123_ahmadinejadatualiza_ac>.

$46<$ https://www.wto.org/english/Tratop_e/dispu_e/cases_e/ds267_e.htm>.
} 
ditadores ou não. Por fim, todos os movimentos citados tiveram final abrupto após a derrubada de seus líderes.

\section{A guerra da cibervigilância: os grampos da NSA à Dilma Rousseff}

A campanha ideológica contra o terrorismo tem início nos EUA após os ataques de 11 de setembro de 2001 e propiciou a assinatura do Patriot Act, que, com a produção de um consenso patriótico em torno de ações de contraterrorismo, dava margem à instauração de um Estado de exceção a partir da abolição do estatuto jurídico dos somente-suspeitos de terrorismo ${ }^{47}$. Ainda permitia, indiscriminadamente, espionagem e coleta de informações de qualquer um que fosse arbitrariamente considerado suspeito. Em seu artigo de 2014, Pires apresenta as três principais formas de cibervigilância exercidas pelas agências nacionais de segurança, como a National Security Agency (NSA) dos EUA. São elas: a receptação de dados diretamente de empresas como o Facebook (com o seu consentimento ou não), por meio do uso dos Programas de Vigilância em Massa (PVM) ou de empresas de espionagem terceirizadas, como a Booz Allen Group (exempregadora de Julian Assange) e a Stratfor (que deu origem à publicação "Global Intelligence Files" do Wikileaks); a interceptação de dados diretamente de cabos submarinos e a indústria de produção de malwares, spywares e trojans ${ }^{48}$.

Em 2013, foi amplamente divulgado na imprensa mundial que a presidente do Brasil à época, Dilma Rousseff, e executivos da Petrobras foram espionados e tiveram seus telefones grampeados pela NSA, o que pode ser comprovado pelo documento "Bugging Brazil", disponibilizado pelo Wikileaks em 07/04/2015 ${ }^{49}$. Dentre os grampeados, estavam não só a Presidente Rousseff, mas ainda pessoas importantes no governo, como o diretor de Assuntos Internacionais do Banco Central Luis Awazu Pereira da Silva, o Ministro-Chefe da Casa Civil Antonio Palocci, o Secretário-executivo do Ministério da Fazenda e posterior Ministro do Planejamento Nelson Barbosa, embaixadores brasileiros no exterior, incluindo também o avião presidencial $^{50}$.

Posto o anterior, é possível considerar que o ocorrido na América do Sul, a partir de 2013, não difere muito do que ocorreu na Primavera Árabe de 2010-2011. No Paraguai, um movimento do congresso depôs o presidente eleito Fernando Lugo. Na Venezuela, foram diversas tentativas de minar o governo de Hugo Chávez e depois de Nicolás Maduro, que são observadas até hoje, inclusive por parte da imprensa internacional, as quais têm sido fortemente reprimidas. $\mathrm{Na}$ Argentina, foi eleito presidente, de forma democrática, o neoliberal Mauricio Macri.

\section{O "Projeto Pontes" (Bridge), a Operação Lava Jato e o Impeachment}

No Brasil, a vitória de Dilma Rousseff nas eleições de 2014 por diferença de 1,6\% dos votos não parecia estar nos planos das redes de poder internacionais. Michel Temer, seu vice-presidente, e que já era contribuinte do Consulado Geral dos EUA em São Paulo ao menos desde $2006^{51}$, quando ainda era Deputado Federal e líder do Partido do Movimento Democrático Brasileiro (PMDB), participou da articulação de seu partido para paralisar votações importantes na Câmara

\footnotetext{
47 Agamben, 2004, p. 14; Pires, 2014, p. 343.

${ }^{48}$ Pires, 2014, p. 346.

$49<$ https://wikileaks.org/nsa-brazil/selectors.html>.

$50<$ https://wikileaks.org/nsa-brazil/>.

$51<$ https://www.wikileaks.org/plusd/cables/06SAOPAULO30_a.html>.
} 
dos Deputados, por intermédio do então Presidente da Câmara Eduardo Cunha, o que aprofundou a crise financeira e política pela qual passava o país. Cunha aceitou o pedido de impeachment de Rousseff, o passo inicial para o início do julgamento político da Presidente (apesar de já estar sendo investigado no período, Cunha só foi preso após o pedido de impeachment ter sido aprovado na Câmara dos Deputados). A opinião pública naquele momento foi fortemente influenciada pela cobertura da "Rede Globo de Televisão", cujos interesses eram nitidamente opostos aos do governo de Dilma, e por organizações como o Movimento Brasil Livre (MBL) e o Vem Pra Rua Brasil, movimentos conservadores de direita que surgiram na cena política após os protestos de junho de 2013, minando radicalmente a popularidade da presidente Dilma Rousseff, que caiu de $65 \%$ de aprovação no mês de março de 2013 para apenas $30 \%$ em julho do mesmo ano ${ }^{52}$.

Paralelamente ao processo de impeachment, corria a Operação Lava Jato, outra ação que ia de acordo com os interesses do governo estadunidense, segundo pode ser observado em telegrama da Embaixada dos EUA em Brasília, assinado por Lise Kubiske (Chefe da Missão Americana no Brasil) em 30/10/2009. O resumo do telegrama, também enviado à Secretaria de Estado Americano diz que:

Uma conferência regional financiada pela Coordenação Estatal para o Contraterrorismo ( $S / C T)$ intitulada "Crimes Financeiros Ilícitos", sediada no Rio de Janeiro entre 4 e 9 de outubro de 2009, reuniu com sucesso representantes do corpo jurídico-legal dos Estados e da União e de países de toda a América Latina. A conferência que durou uma semana inteira foi elogiada em avaliações escritas pelos participantes, com vários deles pedindo por mais treinamentos, inclusive treinamento específico de combate ao terrorismo. Essa solicitação direta se diferencia de solicitações anteriores dos brasileiros, que têm historicamente evitado qualquer treinamento que faça referência ao terrorismo, preferindo em vez disso a termos mais genéricos como "crimes transnacionais". Além do mais, os participantes de forma geral elogiaram o fato de que o treinamento foi multijurisdicional, prático e incluiu demonstrações atuais (como por exemplo "como preparar uma testemunha para depor", e "o exame direto da testemunha"). Futuros treinamentos devem reforçar áreas como "Forças-tarefa de combate ao financiamento ilícito", que podem demonstrar a melhor forma de combater o terrorismo no Brasil ${ }^{53}$.

A conferência supracitada foi a primeira ação coordenada sob a iniciativa do chamado "Projeto Pontes" (Bridge Project), um programa de treinamento conceitual estadunidense, introduzido em fevereiro de 2009, com o objetivo de consolidar o treinamento jurídico bilateral entre EUA e Brasil, focado nas boas-práticas para tratar crimes de colarinho-branco, de financiamento ilícito e de lavagem-de-dinheiro. Incluiu entre os participantes juízes federais de todos os 26 Estados e do Distrito Federal, procuradores e mais de cinquenta agentes da Polícia Federal. Também foram convidados trinta agentes de segurança do nível estadual, entre procuradores e juízes ${ }^{54}$. Segundo o telegrama, os participantes da conferência foram escolhidos de perto pelo Resident Legal

\footnotetext{
${ }^{52}<$ https://www1.folha.uol.com.br/poder/2013/06/1303541-popularidade-de-dilma-cai-27-pontos-aposprotestos.shtml?cmpid=menupe $>$.

$53<$ https://wikileaks.org/plusd/cables/09BRASILIA1282_a.html> Tradução literal do autor.

$54<$ https://wikileaks.org/plusd/cables/09BRASILIA1282_a.html>.
} 
Advisor (RLA) ${ }^{55}$ e o Legal Attaché (LEGAT) ${ }^{56}$. Entre os palestrantes escolhidos estava o juiz federal Sérgio Moro, que tem sua participação relatada no documento:

O Juiz Federal de Crimes de Lavagem-de-dinheiro, Sergio Moro, então discutiu as 15 questões mais comuns que ele observa em casos de lavagem-de-dinheiro nas cortes brasileiras. Apresentadores dos Estados Unidos discutiram diversos aspectos sobre investigação e prossecução de casos de financiamento ilícito e lavagem-de-dinheiro, incluindo cooperações internacionais formais e informais, bloqueio de ativos, métodos de prova, esquemas de pirâmide, acordos de delação premiada, uso do exame direto de testemunha como ferramenta e sugestões sobre como lidar com Organizações Não-Governamentais (ONG) suspeitas de estarem sendo usadas para crimes de financiamento ilícito. Além do mais, foi apresentada uma encenação de uma preparação e exame direto de testemunha ${ }^{57}$.

Na conclusão do telegrama, Lise Kubiske fala sobre os planos para o futuro do projeto e conclui:

\begin{abstract}
TREINAMENTO FUTURO: FORÇA TAREFA DE COMBATE AO FINANCIAMENTO ILÍCITO: [...] A conferência demonstrou claramente que o setor judicial brasileiro está bastante interessado em agir mais proativamente na luta contra o terrorismo, mas precisa das ferramentas e do treinamento para efetivamente se engajar [...] Consequentemente, há uma necessidade contínua de prover treinamentos práticos para os juízes federais e estaduais brasileiros, procuradores e agentes legais a respeito do financiamento ilegal de conduta criminal. Existe um nexo entre os fluxos de dinheiro ilegal e o financiamento do terrorismo, e as cortes legais especializadas em lavagem-de-dinheiro têm se mostrado um método efetivo na acusação de criminosos. Idealmente, o treinamento deve ser de longa duração e coincidir com a formação de forças-tarefa de treinamento. Dois grandes centros urbanos com comprovado suporte judicial contra crimes de financiamento ilícito, em particular São Paulo, Campo Grande ou Curitiba, devem ser selecionados como sede para esse tipo de treinamento. Então, Forças-Tarefa podem ser formadas e uma investigação atual usada como base para o treinamento, que iria sequencialmente progredir na investigação para uma apresentação em audiência e conclusão do caso. Isso daria aos brasileiros a experiência necessária para trabalhar em uma Força-Tarefa proativa de investigação em crimes de financiamento ilícito, e possibilitaria seu acesso aos especialistas dos Estados Unidos para orientação e suporte enquanto atuariam ${ }^{58}$.
\end{abstract}

Segundo o site do Ministério Público Federal (MPF) ${ }^{59}$, a Operação Lava Jato tem início neste mesmo ano, em 2009, com sede na cidade brasileira de Curitiba, e até o presente momento teve como principais alvos os políticos ligados aos governos de Luís Inácio Lula da Silva e Dilma Rousseff, além de executivos da Petrobras e de empreiteiras como a Odebrecht, Queiroz Galvão e Andrade Gutierrez. A Operação Lava Jato viria a se notabilizar pela introdução de práticas até então não usuais nesse tipo de investigação no Brasil, como o uso do método de delação premiada, o bloqueio financeiro sobre investigados e uma participação proativa - por vezes inquisidora - dos juízes.

\footnotetext{
${ }^{55}$ O RLA é um agente do Departamento de Justiça (DOJ) dos EUA encarregado de promover o treinamento e dar consultoria jurídica aos agentes de segurança estrangeiros a fim de combater o terrorismo, o crime organizado, a corrupção e os crimes financeiros <https://www.justice.gov/legal-careers/job/resident-legal-advisor-brazil〉.

${ }^{56}$ Os LEGAT são escritórios do Federal Bureau of Investigation (FBI) fora dos EUA, encarregados de prover o seu governo com informações de contraterrorismo <https:/www.fbi.gov/contact-us/legal-attache-offices>.

$57<$ https://wikileaks.org/plusd/cables/09BRASILIA1282_a.html>. Tradução literal do autor.

$58<$ https://wikileaks.org/plusd/cables/09BRASILIA1282_a.html>. Tradução literal do autor.

${ }^{59}$ Originalmente disponível em < http://www.mpf.mp.br/para-o-cidadao/caso-lava-jato/atuacao-na-1ainstancia/investigacao/historico> e acessado em 27 de junho de 2018 . Verifiquei em 12 de abril de 2020 que a página foi retirada do ar.
} 
Boaventura de Sousa Santos (2002) cita o caso da politização do judiciário e da judicialização da política como um exemplo de "fator de globalização de alta intensidade". Nele, os países centrais, por meio de agências e instituições, atuam no sentido de promover nos países "semiperiféricos e periféricos" reformas jurídicas e judiciais que possibilitem a instauração de uma "institucionalidade jurídica e judicial eficiente e adaptada ao novo modelo de desenvolvimento, assente na prioridade do mercado e das relações mercantis entre cidadãos e agentes econômicos" ${ }^{60}$. Ainda sobre esse processo, Santos (2002) complementa:

[...] este processo é muito rápido e intenso, ocorre pelo impulso de fatores exógenos dominantes, bem definidos e facilmente reconduzíveis a políticas globais hegemônicas interessadas em criar, a nível global, a institucionalidade que facilita a expansão limitada do capitalismo global ${ }^{61}$.

Em 31/06/2016, Dilma Rousseff sofre o impeachment e Michel Temer, então vice-presidente, é empossado como Presidente da República Federativa do Brasil. Em 29/11/2016, menos de seis meses depois, ele sanciona a lei que retira da Petrobras a obrigação de participar com pelo menos $30 \%$ do E\&P em todos os poços do Pré-sal. Na notícia divulgada nesta data pela agência G1 de notícias (veículo on-line da "Rede Globo") é dito que "até hoje o governo só fez um leilão de campo do Pré-sal: o de Libra, que teve apenas um consórcio interessado, formado pela Petrobras, pelos chineses CNOOP e CNPC, pela francesa Total e a anglo-holandesa Shell" e dá voz ao Instituto Brasileiro de Petróleo, Gás e Biocombustíveis (IBP), que afirma que "a mudança tem potencial para destravar os leilões do Pré-sal e alavancar investimentos"62.

Em 07/04/2018, às vésperas do lançamento de sua candidatura à Presidência da República e sendo apontado como favorito em todas as pesquisas de intenção de voto, Luís Inácio Lula da Silva, ex-presidente do Brasil e líder ideológico do PT, foi preso por decisão do juiz federal Sérgio Moro como decorrência de investigações da Operação Lava Jato e, ao ser condenado por um tribunal colegiado, se tornou inelegível, segundo a "Lei da Ficha Limpa" 63.

Nas eleições de 2018, Jair Bolsonaro, antigo político brasileiro de extrema-direita e perfeitamente alinhado aos interesses norte-americanos, é eleito presidente do Brasil e o antes juiz federal Sérgio Moro aceita o convite e se torna Ministro da Justiça e Segurança Pública de seu governo. Posteriormente, em 2018, o site "The Intercept", sob a direção do jornalista norteamericano Glenn Greenwald, começou a divulgar uma série de reportagens evidenciando a parcialidade do ex-juiz federal Sérgio Moro no julgamento do ex-Presidente Lula da Silva, mostrando que esse agiu de forma ilegal, em conjunto com o Ministério Público Federal, com o intuito de condená-lo. Esse vazamento originou uma série de reportagens que ficaram conhecidas como "Vaza-Jato". Uma das reportagens, publicada em 12 de março de 2020, exemplifica a forma de atuação dos agentes estadunidenses em conjunto com a Força-Tarefa da Lava Jato no MPF, durante o governo de Dilma Rousseff. Indica a contradição na participação dos EUA nas investigações em uma latente informalidade institucional, tendo em vista que essa participação ocorreu sem a intermediação do Departamento de Recuperação de Ativos e Cooperação Internacional (DRCI), o órgão competente do Ministério da Justiça - à época comandado por

\footnotetext{
${ }^{60}$ Santos, 2002, p. 88.

${ }^{61}$ Santos, 2002, p. 88.

62 <http://g1.globo.com/economia/noticia/2016/11/temer-sanciona-lei-que-desobriga-petrobras-de-participar-dopre-sal.html $>$.

$63<$ http://pesquisa.in.gov.br/imprensa/jsp/visualiza/index.jsp?jornal=1\&pagina=1\&data=07/06/2010>
} 
José Eduardo Cardozo. Tal fato desrespeita o Tratado Bilateral de Assistência em Assuntos Criminais $^{64}$ assinado pelos dois países em 2001:

Um Tratado Bilateral de Assistência Jurídica Mútua (MLAT) define as regras de como dois países podem cooperar internacionalmente em questões jurídicas, como a solicitação de provas como registros bancários estrangeiros ou relatórios policiais, facilitação de mandados de busca e apreensão, entrevistas de suspeitos estrangeiros e processamento de solicitações de extradição. De acordo com o MLAT e outros tratados relevantes, o Departamento de Recuperação de Ativos e Cooperação Jurídica Internacional (DRCI) do Ministério da Justiça deve ser o ponto de contato do Departamento de Justiça (DOJ) no Brasil, e não representantes do Ministério Público ${ }^{65}$.

As reportagens do "The Intercept" demonstram de que forma se deu o envolvimento de oficiais do Departamento de Justiça dos EUA com as investigações da Operação Lava Jato de modo informal $^{66}$, que culminaram com o pagamento de uma multa de mais de 850 milhões de dólares pela Petrobrás à justiça estadunidense para encerrar as investigações contra ela $-80 \%$ esse valor foi direcionado para o MPF no Brasil ${ }^{67}$. Recentemente, já durante o governo Bolsonaro, a ForçaTarefa de investigação da Lava Jato no MPF foi desfeita.

Outro trecho da mesma reportagem resume a importância das duas principais empresas brasileiras afetadas pela Operação Lava Jato (Petrobras e a construtora Odebrecht) para a soberania nacional e como sua sobrepujança vai de encontro aos interesses dos EUA:

Essas questões foram particularmente constrangedoras para a Operação Lava Jato, já que as investigações envolviam um ex-presidente do partido governante e ainda principal candidato às próximas eleições, de 2018. Em seus oito anos de mandato, Lula trabalhou provocadoramente para construir alianças regionais e enfraquecer a influência dos Estados Unidos no hemisfério. Também sob investigação estavam a Petrobras, joia da coroa da rede de negócios estatais brasileira, e a Odebrecht, a maior construtora do país e que, durante o governo Lula, alavancou suas operações pela América do Sul e além. Ambas as empresas eram vistas como chave para as intenções brasileiras em sua política externa - e como uma ameaça às corporações estadunidenses que elas suplantaram. Em 2013, em um famoso episódio, o governo Rousseff cancelou uma visita de Estado ao Presidente Barack Obama após documentos vazados por Edward Snowden mostrarem que a Agência de Segurança Nacional (NSA) esteve espionando a Petrobras e o Ministro brasileiro de Minas e Energia. O governo dos Estados Unidos, em outras palavras, devia ter interesses em derrubar certas empresas brasileiras que iam além de puramente acabar com a corrupção ${ }^{68}$.

\section{Considerações Finais}

Segundo o exposto é possível entender que a nova geopolítica mundial está se dando, não só por meio bélico, mas também por novas formas de exercício de poder. Na presente era técnicocientífica-informacional, a informação, assim como a velocidade em obtê-la, se torna primordial na definição do poder e da hegemonia mundial. A rede financeira global do capitalismo é uma

\footnotetext{
$64<$ https://www.state.gov/12889>.

65 <https://theintercept.com/2020/03/12/united-states-justice-department-brazil-car-wash-lava-jato-internationaltreaty/>. Tradução literal do autor

$66<$ https://theintercept.com/2020/03/12/united-states-justice-department-brazil-car-wash-lava-jato-internationaltreaty/ $>$.

${ }^{67}<$ https://www.justice.gov/opa/pr/petr-leo-brasileiro-sa-petrobras-agrees-pay-more-850-million-fcpa-violations >

68 <https://theintercept.com/2020/03/12/united-states-justice-department-brazil-car-wash-lava-jato-internationaltreaty/>. Tradução literal do autor.
} 
verticalidade, impondo a racionalidade do lucro (produção de mais-valia) e da máxima eficiência em todos os territórios ${ }^{69}$. A cibervigilância se constitui hoje em uma arma primordial nesse novo tabuleiro geopolítico ${ }^{70}$, visto que a Internet é o lugar onde os fluxos da rede mundial se materializam com maior velocidade, alcançando os pontos nodais do mundo dentro da globalização.

Na geopolítica da hegemonia mundial, os EUA vêm perdendo poder já há algumas décadas ${ }^{71} \mathrm{e}$ cada vez mais recorre ao uso da violência em escala macro territorial para manter o ordenamento mundial no qual se elegeu responsável a partir da pax americana ${ }^{72}$. Porém, além do uso do hard power, surge também o soft power, com novas armas em disponibilidade ${ }^{73}$. O capital, que perdeu sua substância material, hoje é lastreado no porto seguro credor dos EUA e em sua capacidade de promover esse ordenamento e aquecer o seu complexo militar-industrial ${ }^{74}$. Entretanto, após a crise de 2008, vimos o seu endividamento crescente com a emissão de bilhões de dólares do FED para salvar os grandes bancos e empresas à beira do colapso, o que inchou ainda mais a bolha financeira mundial.

O petróleo é o combustível de um sistema capitalista de difícil manutenção, com prazo para esgotar-se, visto que suas reservas são limitadas ${ }^{75}$. Como base do complexo industrial-militar, torna-se peça-chave nas estratégias de posicionamento militar global, visto a necessidade de garantir a sua apropriação, valorização primária, controle de preço, disponibilidade e logística de distribuição. Os territórios da guerra capitalista do século XXI giram em torno dos pontos de E\&P e transporte do petróleo e seus derivados, e isso inclui não só o Oriente Médio, mas o norte da África, a Ásia Central, o Leste Europeu, assim como em menor nível a América do Sul, e, como vimos, também o Brasil.

Os BRICS, que antes vinham em uma ascensão que ameaçava inclusive tornar ultrapassados o FMI, o BID e o Banco Mundial sofreram uma desintegração, e no momento é mais viável falar em uma união China-Rússia do que em um bloco integrado. Com isso, o Brasil vem sendo mais uma vítima nessa guerra informacional-bélica mundial, que expõe seu atual contorno a partir da chamada Primavera Árabe, onde não só a cibervigilância, mas as fake-news e o controle dos think tanks surgem como armas. Seus mais recentes capítulos foram na Ucrânia (Crimeia) e na Síria, ambos reprimidos pela Rússia, e ainda na Turquia e Venezuela, alvos que seus presidentes resistem com violência (Erdogan e Maduro).

Por fim, é possível afirmar que o Estado brasileiro vem sofrendo com ações que ameaçam a sua soberania nacional, o manejo de seus recursos econômicos (como demonstrado aqui com o Présal) e a manutenção de seus serviços públicos básicos, que entram em risco com o fortalecimento das políticas de cunho neoliberal. Entendendo a história, a sociedade e sua geografia como um processo contínuo, dinâmico e repleto de forças e interesses conflitantes, é inegável, diante dos documentos analisados, que os EUA mantiveram participação ativa na política interna brasileira durante o processo de impeachment da presidente Dilma Rousseff, no suporte à Operação Lava Jato (por meio da promoção de treinamentos, consultoria e assistência jurídica), na condenação

\footnotetext{
${ }^{69}$ Santos, 2017.

${ }^{70}$ Pires, 2014, p. 344.

${ }^{71}$ Arrighi e Silver, 2001.

${ }^{72}$ Kurz, 2015; Batista, 1994.

${ }^{73}$ Nye, 2004.

${ }^{74}$ Kurz, 2015.

${ }^{75}$ Altvater, 2010.
} 
da Petrobras e do ex-Presidente Luís Inácio Lula da Silva, e que isso teve como consequência o recrudescimento das políticas neoliberais defendidas desde o Consenso de Washington. Esses fatos não só concedem aos EUA a retomada do domínio geopolítico no continente sul-americano, diminuído nas últimas décadas, mas também beneficiam as empresas petrolíferas com sede em seu território (Chevron e Exxon Mobile) em detrimento das empresas petrolíferas estatais (a brasileira Petrobras, a chinesa SINOPEC e a russa GAZPROM), aumentando assim o seu controle sobre a disponibilidade de petróleo mundial frente aos BRICS e recuperando seu poder sobre o Brasil e a América do Sul.

\section{Bibliografia}

AGAMBEN, Giorgio. Estado de exceção. São Paulo: Boitempo, 2004, $1^{\text {a }}$ ed.

ALTVATER, Elmar. O fim do capitalismo como o conhecemos. Rio de Janeiro: Civilização Brasileira, 2010.

ARRIGHI, Giovanni. O longo século XX. Rio de Janeiro: Contraponto, 1996.

ARRIGHI, Giovanni; SILVER, Beverly J. Caos e governabilidade no moderno sistema-mundo. Rio de Janeiro: Contraponto, 2001.

BACELLAR, Tânia. Dinâmica regional brasileira nos anos noventa: rumo à desintegração competitiva? In: CASTRO, MIRANDA et EGLER. Redescobrindo o Brasil: 500 anos depois. Rio de Janeiro: Bertrand Brasil, 1999, $2^{a}$ ed.

BATISTA, Paulo Nogueira. O Consenso de Washington: a visão neoliberal dos problemas latino-americanos. Rio de Janeiro: PEDEX, 1994.

BRAUDEL, Fernand. Civilização material, economia e capitalismo: séculos XV-XVIII: o tempo do mundo, Volume III. São Paulo: Martins Fontes, 2009, $2^{\text {a }}$ ed.

HARVEY, David. The new imperialism. Oxford: Oxford University Press, 2003.

KURZ, Robert. Poder mundial e dinheiro mundial: crônicas do capitalismo em declínio. São Paulo: Consequência, 2015.

MARTINEZ, E. D. M.; LIVEIRA, T. F. de. Políticas neoliberais na América Latina: uma análise comparativa dos casos no Brasil e Chile. Revista de Estudos Internacionais (REI), vol. 7, n. 1, 2016.

NYE, Joseph S. Soft power: the means to success in World politics. New York: PublicAffairs, $2004,1^{\text {a }}$ ed.

PIRES, Hindenburgo Francisco. Indústrias globais de vigilância em massa: o controle do cibesespaço. In: OLIVEIRA, F. G., FREIRE, D. G., MASCARENHAS, G., OLIVEIRA, L. D. (Orgs.). Geografia Urbana: ciência e ação política. Rio de Janeiro: Consequência, 2014. 
PIRES, Hindenburgo Francisco. Globalização e integração financeira e tecnológica entre os países emergentes: o novo banco de desenvolvimento dos BRICS. GeoUERJ, v. 1, p. 283-292, 2015.

ROLNIK, Raquel. Guerra dos Lugares: A colonização da terra e da moradia na eradas finanças. São Paulo: Boitempo, 2015.

SANTOS, Boaventura de Sousa. Os processos da globalização. In: SANTOS, Boaventura de Sousa (Org.). A globalização e as ciências sociais. São Paulo: Cortez, 2002.

SANTOS, Milton. A natureza do espaço. São Paulo: EdUSP, n. 9, 2017, $4^{\mathrm{a}}$ ed.

WALLERSTEIN, Immanuel. The Politics of the World-economy: the States, the Movements and the Civilizations. Cambridge: Cambridge University Press, 1984.

WILHELM, Vandiana Borba. A Trajetória do Neoliberalismo na Venezuela e sua Conjuntura Atual: uma análise das políticas governamentais desencadeadas a partir do ano de 1998. Rebela. Revista Brasileira de Estudos Latino-americanos, v. 1, n. 2, p. 252-275, 2011.

\section{Referências Eletrônicas}

AGÊNCIA PÚBLICA. A nova roupa da direita. [On-line]. AMARAL, Marina. Agência Pública, São Paulo. Publicado em 23 de junho de 2015. < https://apublica.org/2015/06/a-novaroupa-da-direita/>. [10 de junho de 2020].

BBC. Lula recebe Ahmadinejad em meio a polêmica. [On-line]. BBC, São Paulo. Publicado em 23 de novembro 2009. <https://www.bbc.com/portuguese/noticias/2009/11/091123_ahmadinejadatualiza_ac>. [12 de abril de 2020].

BRASIL. Lei Complementar $\mathrm{n}^{\mathrm{o}}$ 135, de 4 de junho de 2010. Altera a Lei Complementar $\mathrm{n}^{\mathrm{0}}$ 64, de 18 de maio de 1990, que estabelece, de acordo com o $\S 9^{\circ}$ do art. 14 da Constituição Federal, casos de inelegibilidade, prazos de cessação e determina outras providências, para incluir hipóteses de inelegibilidade que visam a proteger a probidade administrativa e a moralidade no exercício do mandato. Diário Oficial da União: seção 1, Brasília, DF, ano CXLVII, n. 106, p. 12, 7 jun. 2010. [On-line]. <http://pesquisa.in.gov.br/imprensa/jsp/visualiza/index.jsp?jornal=1\&pagina $=1 \&$ data $=07 / 06 / 2$ 010>. [09 de junho de 2020].

CARTA CAPITAL. Quem são os Irmãos Koch?. [On-line]. COSTA, Antônio Luiz M. C. Carta Capital, São Paulo. Publicado em 23 de março de 2015. <https://www.cartacapital.com.br/politica/quem-sao-os-irmaos-koch-2894/>. [10 de junho de 2020].

CARTA MAIOR. A Líbia, a OTAN e o Grande Médio Oriente. [On-line]. FIORI, José Luís. Carta Maior, São Paulo. Publicado em 31 de agosto de 2011. <https://www.cartamaior.com.br/?/Coluna/A-Libia-a-Otan-e-o-Grande-Medio-

Oriente/20882/>. [10 de junho de 2020]. 
DICIONÁRIO DO PETRÓLEO EM LÍNGUA PORTUGUESA. E\&P / Exploration and Production [On-line]. FERNANDEZ Y FERNANDEZ, Eloi; PEDROSA JR., Oswaldo; PINHO, Antônio Correia de. <http://dicionariodopetroleo.com.br/dictionary/ep/>. [12 de abril de 2020].

ESTADÃO. ONU autoriza intervenção na Líbia. [On-line]. CHACRA, Gustavo; RAATZ, Luiz. Estadão, São Paulo. Publicado em 17 de março de 2011. <https://internacional.estadao.com.br/noticias/geral,onu-autoriza-intervencao-nalibia,693415>. [10 de junho de 2020].

FOLHA DE SÃO PAULO. Popularidade de Dilma cai 27 pontos após protestos. [On-line]. MENDONÇA, Ricardo. Folha de S. Paulo, São Paulo. Publicado em 29 de junho de 2013. $<$ https://www1.folha.uol.com.br/poder/2013/06/1303541-popularidade-de-dilma-cai-27pontos-apos-protestos.shtml?cmpid=menupe $>$. [14 de abril de 2020].

G1. Temer sanciona lei que desobriga Petrobras de participar do pré-sal. [On-line]. LIS, Laís e AMARAL, Luciana. G1, Brasília. Publicado em 29 de novembro de 2016. <http://g1.globo.com/economia/noticia/2016/11/temer-sanciona-lei-que-desobriga-petrobrasde-participar-do-pre-sal.html>. [12 de abril de 2020].

MINISTÉRIO PÚBLICO FEDERAL. Histórico da Operação Lava Jato. [On-line]. $<$ http://www.mpf.mp.br/para-o-cidadao/caso-lava-jato/atuacao-na-1ainstancia/investigacao/historico>. [27 de junho de 2018].

MOHAMMED BIN RASHID SCHOOL OF GOVERNMENT. Arab Social Media Report. [Online]. <https://www.arabsocialmediareport.com/home/index.aspx/>. [10 de junho de 2020].

THE INTERCEPT. Secret Brazil Archive Part 13: Leaked chat logs show that Brazilian prosecutors evaded treaties to help the U.S. Justice Department investigate Brazilian corporations. [On-line]. FISHMAN, Andrew; VIANA, Natalia; SALEH, Maryam. The Intercept Brasil, Rio de Janeiro. Publicado em 12 de março de 2020. $<$ https://theintercept.com/2020/03/12/united-states-justice-department-brazil-car-wash-lavajato-international-treaty/>. [12 de abril de 2020].

THE RIO TIMES. New U.S Ambassador Arrives in Brazil. [On-line]. Publicado em: 16 de março de 2010. OLSON, Mira. The Rio Times, Rio de Janeiro. <http://riotimesonline.com/brazilnews/rio-politics/new-u-s-ambassador-arrives-in-brazil/>. [12 de abril de 2020].

U.S. DEPARTMENT OF JUSTICE. Legal Careers: Resident Legal Advisor - Brazil. [On-line]. Office of Overseas Prosecutorial Development Assistance and Training. Atualizado em 7 de abril de 2016. <https://www.justice.gov/legal-careers/job/resident-legal-advisor-brazil>. [10 de junho de 2020].

U.S. DEPARTMENT OF JUSTICE. Petróleo Brasileiro S.A.: Petrobras Agrees to Pay More Than $\$ 850$ Million for FCPA Violations. [On-line]. Office of Public Affairs. Publicado em 27 de setembro de 2018. <https://www.justice.gov/opa/pr/petr-leo-brasileiro-sa-petrobras-agreespay-more-850-million-fcpa-violations $>$. [12 de abril de 2020].

U.S. DEPARTMENT OF JUSTICE. Overseas Offices. [On-line]. Federal Bureau of Investigation. <https://www.fbi.gov/contact-us/legal-attache-offices>. [10 de junho de 2020]. 
U.S. DEPARTMENT OF STATE. Brazil (12889): Treaty on Mutual Legal Assistance in Criminal Matters. [On-line]. Office of Treaty Affairs. Publicado em 21 de fevereiro de 2001. $<$ https://www.state.gov/12889>. [12 de abril de 2020].

UOL. Governo zera IPI de carro 1.0, reduz IOF do crédito e dá mais prazo para financiar. [Online]. UOL, São Paulo. Publicado em 21 de maio de 2012. $<$ https://economia.uol.com.br/noticias/redacao/2012/05/21/governo-zera-ipi-de-carro-10-e-damais-prazo-para-financiar.htm>. [12 de abril de 2020].

WIKILEAKS. PMDB Leader ponders party's electoral options. MCMULLEN, Cristopher. Consulado Geral dos Estados Unidos da América em São Paulo, 11 de janeiro de 2006. <https://www.wikileaks.org/plusd/cables/06SAOPAULO30_a.html>. [26 de junho de 2018].

WIKILEAKS. Brazil: Illicit Finance Conference uses the "T" word, successfully. [On-line]. KUBISKE, Lise. Embaixada dos Estados Unidos da América em Brasília, 30 de outubro de 2009. <https://wikileaks.org/plusd/cables/09BRASILIA1282_a.html>. [26 de junho de 2018].

WIKILEAKS. Can the oil industry beat back the Pre-Salt law? [On-line]. HEARNE, Dennis W. Consulado Geral dos Estados Unidos da América no Rio de Janeiro, 2 de dezembro de 2009. <https://search.wikileaks.org/plusd/cables/09RIODEJANEIRO369_a.html>. [26 de junho de 2018].

WIKILEAKS. Brazil's Presidential Elections: Dilma Rousseff comes up fast behind Jose Serra. [On-line]. SHANNON, JR., Thomas. Embaixada dos Estados Unidos da América em Brasília, 13 de fevereiro de 2010. <https://wikileaks.org/plusd/cables/10BRASILIA49_a.html>. [26 de junho de 2018].

WIKILEAKS. PlusD. [On-line]. <https://wikileaks.org/plusd/about/>. [27 de junho de 2018].

WIKILEAKS. Bugging Brazil. [On-line]. <https://wikileaks.org/nsa-brazil>. [12 de abril de 2020].

WIKILEAKS. NSA high priority targets for Brazil. [On-line]. <https://wikileaks.org/nsabrazil/selectors.html>. [12 de abril de 2020].

WORLD BANK. Data: Final consumption expenditure (annual \% growth) - China, United States, India, United Kingdom. [On-line]. $<$ https://data.worldbank.org/indicator/NE.CON.TOTL.KD.ZG?end=2018\&locations=CN-USIN-GB\&start=2000>. [8 de junho de 2020].

WORLD BANK. Data: GDP growth (annual \%) - China, United States, India, United Kingdom. [On-line]. $<$ https://data.worldbank.org/indicator/NY.GDP.MKTP.KD.ZG?end=2018\&locations=CN-USIN-GB\&most_recent_year_desc=false\&start=2000\&view=chart $>$. [10 de junho de 2020].

WORLD BANK. Data: Industry (including construction), value added (current US\$) - China, United States, India, Kingdom. [On-line]. $<$ https://data.worldbank.org/indicator/NE.CON.TOTL.KD.ZG?end=2018\&locations=CN-USIN-GB\&start=2000>. [8 de junho de 2020]. 
WORLD TRADE ORGANIZATION (WTO). DS267: United States - Subsidies on Upland Cotton. [On-line]. <https://www.wto.org/english/Tratop_e/dispu_e/cases_e/ds267_e.htm>. Publicado em: 16 de outubro de 2014. [8 de junho de 2018].

(c) Copyright: Gabriel Teixeira Barros, 2020.

(C) Copyright: Ar@cne, 2020.

Ficha bibliográfica:

BARROS, Gabriel Teixeira. A virada geopolítica no Brasil do século XXI observada a partir de telegramas diplomáticos vazados pelo Wikileaks.Ar@cne. Revista Electrónica de Recursos de Internet sobre Geografía y Ciencias Sociales. Barcelona: Universidad de Barcelona, 1 de julio de 2020, vol. XXIV, ${ }^{\circ} 244$ <https://doi.org/10.1344/ara2020.244.31817>.

\section{Menú principal de Geo Crítica}

